\title{
Production and In Vitro Digestibility of Leucaena leucocephala Under Different Seasons and Planting Model Systems in Kupang Regency, Indonesia
}

\author{
Edi Djoko Sulistijo ${ }^{1,2^{*}} \quad$ Ifar Subagyo $^{3} \quad$ Siti Chuzaemi $^{3}$ Herni Sudarwati ${ }^{3}$ \\ 1.Doctoral Student of Faculty of Animal Science, University of Brawijaya, Malang 65145, Indonesia \\ 2.Lecturer of Faculty of Animal Husbandry, Universitas Nusa Cendana, Kupang 85228, Indonesia \\ 3.Lecturer of Faculty of Animal Science, University of Brawijaya, Malang 65145, Indonesia
}

\begin{abstract}
Farmers in Kupang had 3 different Leucaena leucocephala plantations with each was planted under different local planting methods as their forage resource. In this research, we evaluate the production, nutritional content and in vitro digestibility of the L. leucocephala in all of the plantations during the early and late dry season as well as during rainy season. The first plantation was planted under Amarasi model (Amarasi plantation), where the $L$. leucocephala were planted in array; the second plantation was planted under Mamar Kering model (Mamar Kering plantation), where the L. leucocephala were planted by the natural fauna of the plantation; and the third plantation was planted under Selobua model (Selobua plantation), where the L. leucocephala were planted intercropping with crops. The harvest was done every four months from March 2016 to April 2017 by also following local harvesting practices (all of the branches and leaves were cut at 2-3 $\mathrm{m}$ above ground). The observed variables include dry matter $(\mathrm{DM})$, organic matter $(\mathrm{OM})$, crude protein $(\mathrm{CP})$, neutral-detergent fiber (NDF), and acid detergent fiber (ADF) content, as well as the in vitro DM and OM digestibility of $L$. leucocephala. All of the obtained data were analyzed with nested ANOVA and followed with LSD test. The results showed that different planting model and season gave differences $(\mathrm{P}<0.01)$ to the DM, NDF, ADF, in vitro DM and OM digestibility. The study concluded that the Amarasi plantation had the highest production, while overall nutritional content and in vitro digestibility of L. leucocephala was better during rainy season, and the highest was found in Selobua plantation.
\end{abstract}

Keywords: Amarasi, Mamar Kering, Selobua, forages, Leucaena leucocephala

DOI: $10.7176 / \mathrm{JBAH} / 10-2-05$

Publication date: January $31^{\text {st }} 2020$

\section{Introduction}

The forage availability for livestock feed has become a common issue whether in an intensive or extensive farming system. The currently available solutions are whether by providing forage plantation, conducting integrated livestock to crop farming system or utilizing different forages in mixed farming systems (Makar, 2002; Simbaya, 2002; Smith, 2002; Delsalle et al., 2012). In some places, specific and local practices were done to overcome the threat of feed shortages, yet there was little, if none, comprehensive research available to measure its production. In Kupang Regency, the local practices include Amarasi, Mamar Kering, and Selobua planting system were used for Leucaena leucocephala plantation.

In the Amarasi planting system, the L. leucocephala were planted in an array with tight spaces between each plant, while in Mamar Kering, the L. leucocephala seeds were planted by the local fauna of the plantation, thus resulted in scattered L. leucocephala plants and growth along with other perennials. The third planting system is called Selobua, where the L. leucocephala was planted intercropping with crops for human consumption (Nulik et al., 2000; Roshetko \& Mulawarman, 2002; Njurumana, 2008; Kapa, 2007; Sulistijo \& Rosnah, 2013).

Previous research on the utilization of forage plantation to support livestock farming in the Kupang Regency has been widely available. However, a quantitative approach to measure the forage production planted with different local practices has yet to be done. In this research, we evaluate the production, nutritional content and in vitro digestibility of L. leucochepala produced with Amarasi, Mamar Kering and Selobua planting models during early and late dry season as well as during rainy season. The obtained results are expected to contribute to the forage science, especially land utilization as feed source. 


\section{Methodology}

\subsection{Time and Location}

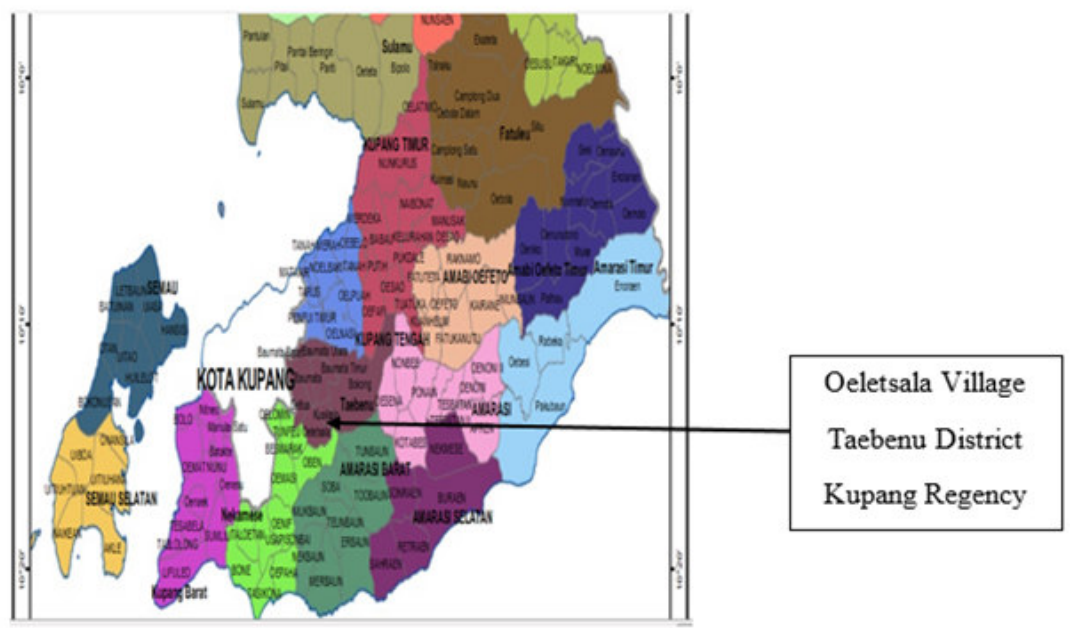

Figure 1. Research location

The research was done in Oeletsala Village, Taebenu District, Kupang Regency, as our previous research (Sulistijo \& Rosnah, 2013) showed that the Amarasi, Mamar Kering, and Selobua planting systems for $L$. leucocephala were only found in the area. Each of the planting systems was located in different plantations, henceforth will be written as Amarasi plantation, Mamar Kering plantation, and Selobua plantation. The sample was collected from March 2016 to April 2017. The initial trimming was done in March to April 2016 to homogenize the sample and then followed by harvesting from July to August 2016 for early dry season sample, November to December 2016 for late dry season sample, and March to April 2016 for rainy season sample. The location of Oeletsala Village is presented in Figure 1, while the overview of the land condition and each plantation is presented in Figure 2.

\subsection{Materials}

The materials used in this research include Leucaena leucocephala and chemicals used for the nutritional content analysis (dry matter/DM, organic matter/OM, crude protein/CP, neutral-detergent fiber/NDF, and acid detergent fiber/ADF content) and in vitro digestibility.

\subsection{Methods}

The research was conducted through a field survey method, and the sample was collected by following Noele geological formation, with 4 areas in each plantation were chosen for analysis. Moreover, the sample collection was done by following the local practice, where L. leucocephala leaves and branches were cut at 2-3 m above ground. The proximate analysis to measure the DM, OM, and CP was done by following AOAC (1980), the NDF and ADF content were measured by following Goering \& Van Soest (1970), and the DM and OM in vitro digestibility were done by following Tilley \& Terry (1963).

\subsection{Data Analysis}

The analysis was done with four replications, and the obtained data were analyzed by using analysis of variance with the nested design, followed with LSD test to measure the significances. The combined treatments consisted of plantation (Amarasi, Mamar Kering, and Selobua plantation) and season (early dry season, late dry season, and rainy season). The analysis model used is as follow:

$$
\begin{aligned}
& \text { where: } \\
& Y_{i j k}=\mu+T_{i}+\beta_{j(i)}+\epsilon_{i j(k)} \text {; }
\end{aligned}
$$



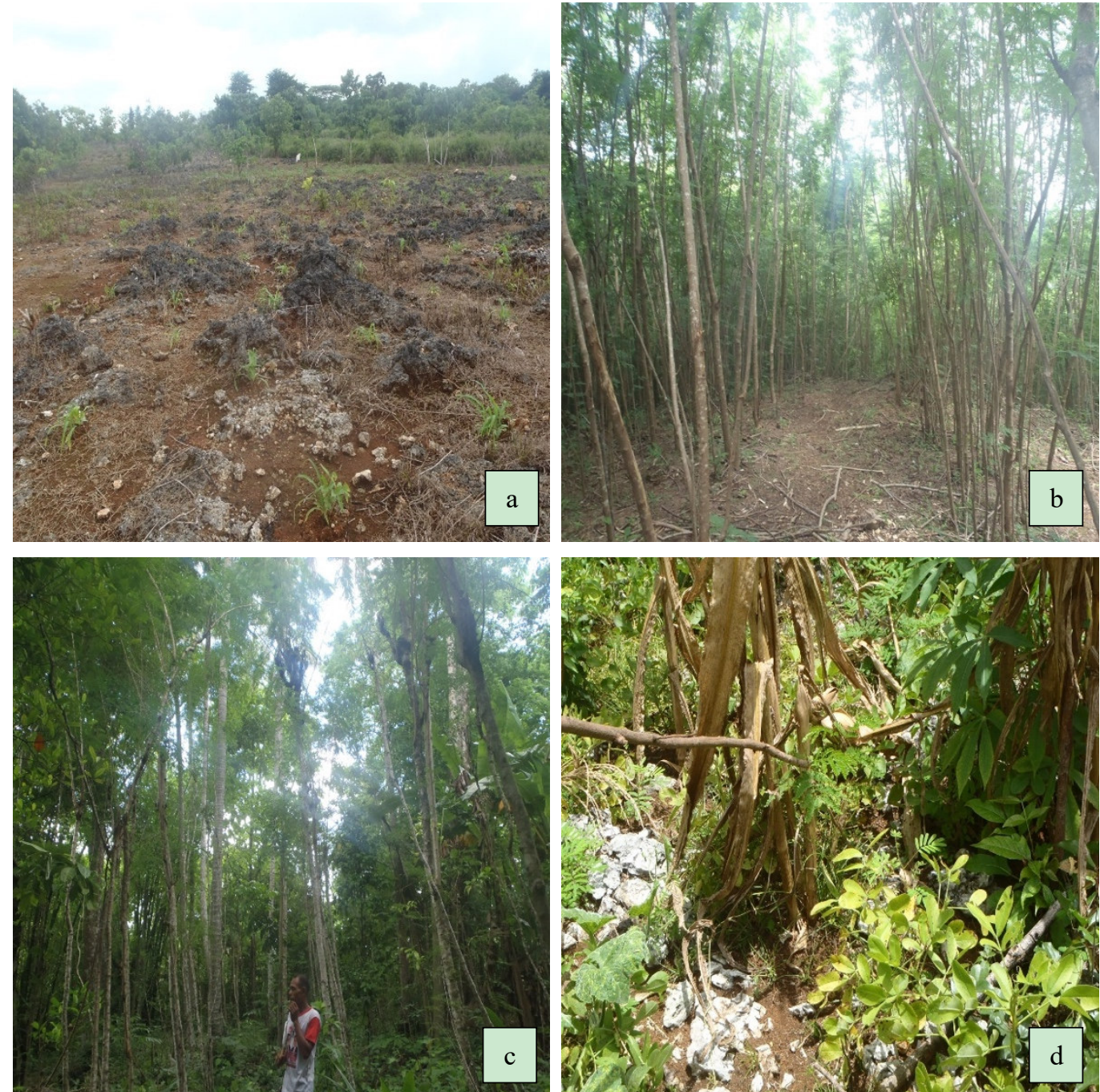

Figure 2. Overview of the land condition (a); Amarasi plantation (b); Mamar Kering plantation (c); and Seloboa plantation (d)

\section{Results and Discussions}

\subsection{Forages Production}

The L. leucocephala production under different seasons and plantations is presented in Table 1 . The results showed that $L$. leucocephala production was ranged from $453.04 \mathrm{~kg} \mathrm{DM} / \mathrm{Ha} / 4$ months to $1,830.97 \mathrm{~kg} \mathrm{DM} / \mathrm{Ha} / 4$ months or equals to 1,359 tons/Ha/year to 5,493 tons/Ha /year. The results are still in the production standard per unit area as explained by Mannetje \& Jones (2000). 
Table 1. L. leucochepala production based on a different season and planting system (in DM)

Treatments Forages Production (kg DM/Ha/4 months)

\section{Plantation system}

\begin{tabular}{|l|c|}
\hline Amarasi & $1,830.97 \pm 388.67^{\mathrm{c}}$ \\
\hline Mamar Kering & $453.04 \pm 147.20^{\mathrm{a}}$ \\
\hline Selobua & $878.88 \pm 256.59^{\mathrm{b}}$ \\
\hline Different seasons in Amarasi plantation & $1,615.41 \pm 345.22^{\mathrm{a}}$ \\
\hline Early dry season & $1,861.12 \pm 381.44^{\mathrm{a}}$ \\
\hline Late dry season & $2,016.39 \pm 424.52^{\mathrm{a}}$ \\
\hline Rainy season & $494.48 \pm 11.08^{\mathrm{a}}$ \\
\hline Different seasons in Mamar Kering plantation & $549.75 \pm 81.42^{\mathrm{a}}$ \\
\hline Early dry season & $314.89 \pm 142.39^{\mathrm{a}}$ \\
\hline Late dry season & \\
\hline Rainy season & $923.97 \pm 244.23^{\mathrm{a}}$ \\
\hline Different seasons in Selobua plantation & $812.94 \pm 222.83^{\mathrm{a}}$ \\
\hline Early dry season & $899.71 \pm 350.74^{\mathrm{a}}$ \\
\hline Late dry season & \\
\hline Rainy season & \\
\hline
\end{tabular}

Note: The different superscripts in different plantations indicate highly significant differences $(\mathrm{p}<0.01)$.

The statistical analysis showed that different planting model systems affect $(\mathrm{p}<0.01)$ L. leucocephala production, while different seasons did not affect $(\mathrm{p}>0.05)$ the production. The production measurement showed that the produced L. leucocephala in Amarasi plantation was higher compared to Mamar Kering and Selobua. The result is expected as the L. leucocephala in Mamar Kering and Selobua plantations had unequal densities. The result is supported by the research by Elfeed \& Elmagboul (2016) which showed the dense L. leucocephala population planted in the dry climatic regions would provide higher total production.

The similar L. leucocephala production on different seasons indicates that the harvesting of L. leucocephala in every four months did not disrupt its growth. Moreover, during dry seasons (early and late), the rainfalls still occurred. The conditions would provide plenty moisture and water in the soil on the dry climate. The rainfall intensity during this study is presented in Figure 3.

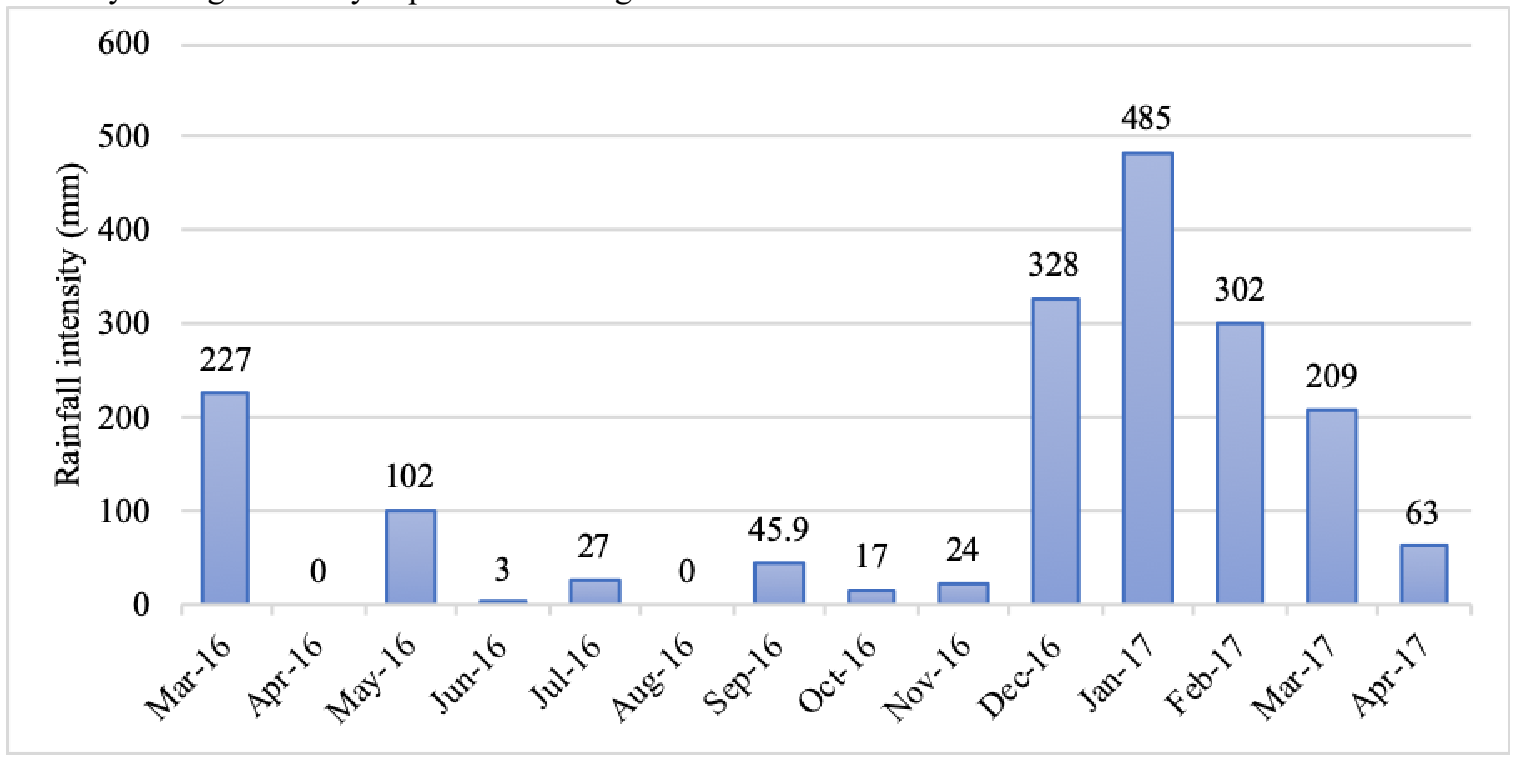

Figure 3. Rainfall intensity during research

\subsection{Nutritional Content}

The statistical analysis showed that the different seasons and plantations affect $(\mathrm{p}<0.01)$ the nutritional content of L. leucocephala (Table 2). The results showed that different planting systems affect $(\mathrm{p}<0.01)$ the OM, NDF, and ADF content. Moreover, the different seasons on every plantation affect $(\mathrm{p}<0.01)$ the DM, OM, NDF and ADF contents of L. Leucocephala.

The results showed that the highest DM, NDF and ADF content of L. leucochepala were found in the Amarasi plantation. In contrast, the highest $\mathrm{OM}$ and CP contents were found in the Selobua plantation. Furthermore, analysis of the different seasons in each plantation showed that the highest DM of L. leucocephala 
was obtained during late dry season, while the highest NDF and ADF content was found during the rainy season. In addition, the OM of $L$. leucocephala in Mamar Kering plantation was not different during all seasons, while the OM in Amarasi and Selobua plantation found to be the highest during rainy season. The CP content of $L$. leucocephala in Amarasi and Mamar Kering plantation in all seasons was not different, while lower CP content of L. leucocephala was found during late dry season.

Table 2. Nutritional composition of the L. leucochepala on each treatment

\begin{tabular}{|c|c|c|c|c|c|}
\hline Treatment & DM (\%) & OM (\%) & CP (\%) & NDF (\%) & ADF (\%) \\
\hline \multicolumn{6}{|l|}{ Plantation } \\
\hline Amarasi & $30.01^{\mathrm{b}}$ & $90.54^{\mathrm{a}}$ & $18.83^{\mathrm{a}}$ & $46.11^{\mathrm{b}}$ & $36.54^{\mathrm{b}}$ \\
\hline Mamar Kering & $26.98^{\mathrm{a}}$ & $91.11^{\mathrm{ab}}$ & $18.78^{\mathrm{a}}$ & $46.49^{\mathrm{b}}$ & $36.72^{\mathrm{b}}$ \\
\hline Selobua & $29.54^{\mathrm{b}}$ & $91.63^{\mathrm{b}}$ & $20.00^{\mathrm{b}}$ & $44.59^{\mathrm{a}}$ & $34.52^{\mathrm{a}}$ \\
\hline \multicolumn{6}{|c|}{ Different seasons in Amarasi plantation } \\
\hline Early dry season & $30.57^{b}$ & $89.38^{\mathrm{a}}$ & $18.36^{\mathrm{a}}$ & $46.16^{\mathrm{b}}$ & $35.21^{\mathrm{b}}$ \\
\hline Late dry season & $36.94^{\mathrm{c}}$ & $90.62^{\mathrm{a}}$ & $18.41^{\mathrm{a}}$ & $39.08^{\mathrm{a}}$ & $31.07^{\mathrm{a}}$ \\
\hline Rainy season & $22.54^{\mathrm{a}}$ & $91.62^{\mathrm{b}}$ & $19.71^{\mathrm{a}}$ & $53.09^{\mathrm{c}}$ & $43.35^{\mathrm{c}}$ \\
\hline \multicolumn{6}{|c|}{ Different seasons in Mamar Kering plantation } \\
\hline Early dry season & $28.07^{b}$ & $91.23^{\mathrm{a}}$ & $18.80^{\mathrm{a}}$ & $45.59^{\mathrm{b}}$ & $34.77^{\mathrm{a}}$ \\
\hline Late dry season & $30.56^{\mathrm{b}}$ & $90.56^{\mathrm{a}}$ & $18.32^{\mathrm{a}}$ & $40.65^{\mathrm{a}}$ & $32.72^{\mathrm{a}}$ \\
\hline Rainy season & $22.31^{\mathrm{a}}$ & $91.54^{\mathrm{a}}$ & $19.20^{\mathrm{a}}$ & $53.23^{\mathrm{c}}$ & $42.68^{\mathrm{b}}$ \\
\hline \multicolumn{6}{|c|}{ Different seasons in Selobua plantation } \\
\hline Early dry season & $30.54^{\mathrm{b}}$ & $91.37^{\mathrm{a}}$ & $20.20^{\mathrm{b}}$ & $44.06^{\mathrm{b}}$ & $32.83^{\mathrm{a}}$ \\
\hline Late dry season & $36.65^{\mathrm{c}}$ & $90.15^{\mathrm{a}}$ & $18.43^{\mathrm{a}}$ & $39.29^{\mathrm{a}}$ & $32.36^{\mathrm{a}}$ \\
\hline Rainy season & $21.42^{\mathrm{a}}$ & $93.37^{\mathrm{b}}$ & $21.38^{\mathrm{b}}$ & $50.43^{\mathrm{c}}$ & $38.35^{\mathrm{b}}$ \\
\hline
\end{tabular}

Note: The different superscripts in different plantations indicate highly significant differences $(p<0.01)$; while the different superscripts in combined different seasons and plantations showed significant differences $(p<0.05)$. $\mathrm{OM}, \mathrm{CP}, \mathrm{NDF}$, and ADF were based on the \%DM.

The DM content of L. leucochepala in Mamar Kering plantation was lower (26.98\%) compared to Selobua plantation (29.54\%) and Amarasi plantation (30.01\%). Mamar Kering plantation is dominated by perennial plants, thus resulted in the condition where L. leucocephala grown under shades. This condition could disrupt photosynthesis and reduce the transpiration, which in turn would affect the DM content in plant biomass. The lower DM content on plants grown under shade has been shown on research by Handriawan et al. (2016) and Chairudin et al. (2015).

As seen in Table 2, the OM content of L. leucocephala in Selobua plantation (91.63\%) was similar to Mamar Kering plantation (91.11\%) but higher than Amarasi plantation (90.54\%). This can be caused by the higher soil nitrogen in Selobua plantation (0.28\%), which is higher than that of the Amarasi (0.07\%) and Mamar Kering $(0.07 \%)$ plantation. Plants that grow in high soil nitrogen will grow better and accumulate photosynthetic $\mathrm{OM}$ as the results. The similar condition has been shown by Koten et al. (2012) for sorghum (Sorghum bicolor (L.) Moench) and Keraf et al. (2015) on Kume grass (Sorghum plumosum var. Timorense).

The OM content between harvesting periods the Mamar Kering plantation did not differ caused by the high presence of L. leucocephala stands under the shade. Mamar Kering plantation was dominated by perennial trees, so the microclimate and soil moisture tend to be similar throughout the year. The conditions resulted in photosynthesis inhibition and similar growth of $L$. leucocephala as reflected in the OM content of $L$. leucocephala in all seasons. From Table 2, it can be seen that the CP content of L. leucocephala was ranged from 18.32 to $21.38 \%$. The CP content is lower than other research on L. leucocephala which ranged from $22.16 \%$ to 31.8\% (Aregheore, 2002; Edward et al., 2012; Soltan et al., 2012; Rimbawanto et al., 2015). The different CP content is allegedly due to the different biomass on leaves and branches fraction. Research by Sulistijo (1994) on gliricidia found that the CP content in leaves is higher compared to the edible stem. This is also in line with Askar (1997) which showed that varied CP content of forage would be affected by the proportion between leaves and petioles aside from the forage varieties, soil fertility, age, and climate. The CP content of L.leucochepala in Selobua plantation (20.00\%) was higher than Mamar Kering (18.78\%) and Amarasi (18.83\%) plantation.

Moreover, the soil in Selobua plantation was more fertile compared to other plantations as reflected by higher soil nitrogen. The more fertile soil conditions would lead to better growth of shoots, branches, and leaves. The application of nitrogen fertilizer would also increase the leaf's area and higher photosynthetic velocity, thus resulted in an increase of CP content (McDonald et al., 2010). In Table 2, it can also be seen that the different CP content on different seasons was only found in Selobua plantation. The CP content in Selobua plantation during rainy season was $21.38 \%$, while during early dry and late dry seasons were $20.20 \%$ and $18.43 \%$, respectively. Both Amarasi, Mamar Kering and Selobua plantations were located in the dry and barren area, thus water availability becomes the major factor in determining plant's growth. The water availability in soil would 
support the utilization of soil nitrogen by plants. The similar water availability in all plantations is then lead to the higher nitrogen soil Selobua plantation as the determining factor which affects different CP content, even though further confirmations in regard to this matter would be recommended.

The NDF and ADF content of L. leucocephala in this research were ranged from 39.08 to $53.23 \%$ and 31.07 to $42.68 \%$, respectively. The obtained NDF and ADF content were higher compared to other research (Aegheore, 2002; Edward et al., 2012; Soltan et al., 2012) which showed that the NDF of L. leucocephala were ranged from 33.6 to $49.1 \%$ and the ADF were 22.8 to $42.11 \%$. Moreover, the trend of NDF and ADF content of L. leucocephala on each plantation in this research was in contrast to the respective CP content. The results indicate that the higher available nitrogen soil would result in higher L. leucocephala along with its CP and lower fiber content. In regards to the result, research by Egan et al., (1985) showed that NDF is a less soluble compound, consisted of cellulose, hemicellulose, and lignin, which build the cell walls along with ADF. The higher CP, which builds the cell nucleus would the growth of cell wall growth, and thus resulted in lower NDF and ADF of the plant (Crowder \& Chheda, 1982).

\subsection{In Vitro Digestibility}

The in vitro digestibility of DM (IVDM) and OM (IVOM) in this research are presented in Table 3 . The statistical analysis showed that the different planting models resulted in different $(p<0.01)$ in vitro digestibility of L. leucocephala, with the different seasons, resulted in different $(\mathrm{P}<0.05)$ in vitro digestibility as well. In Table 3 , it can be seen that the highest IVDM and IVOM of L. leucocephala were found on Selobua plantation. The results were regarding the higher CP content and lower NDF and ADF content of L. leucocephala in Selobua plantation. Kim \& Jang (1988) showed that higher CP content would have resulted in higher digestibility, while higher fiber content would have resulted in lower digestibility.

Table 3. Digestibility of lamtoro forages based on garden type and harvest period

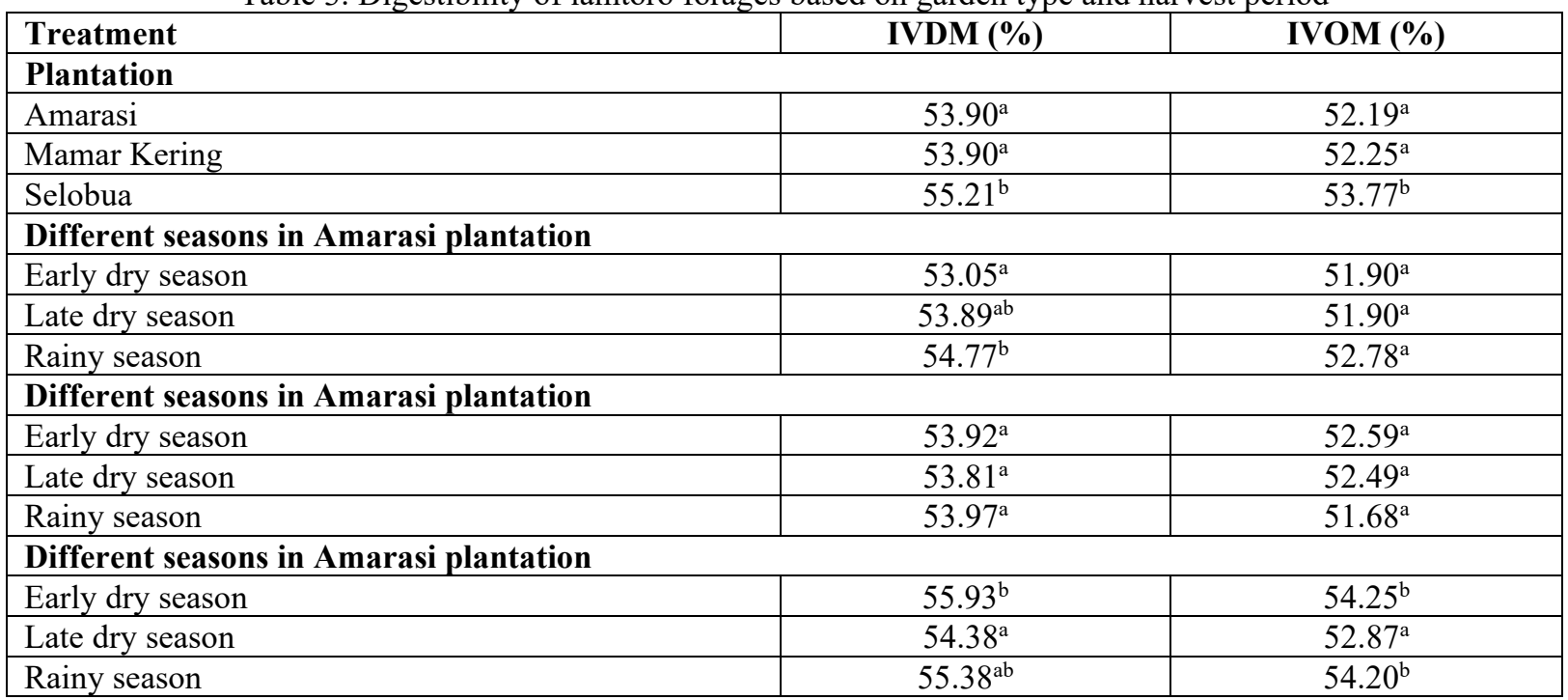

Note: The different superscripts in different plantations indicate highly significant differences $(\mathrm{p}<0.01)$; while the different superscripts in combined different season and plantation showed significant differences $(p<0.05)$.

In Table 3 , it can also be seen that different seasons and planting systems did not give significant effects. However, there is a tendency that the rainy and early dry seasons have resulted in better in vitro digestibility of $L$. leucocephala. The condition is caused by higher CP content and lowers NDF content of L. leucocephala due to the higher water availability in those seasons. According to McDonald et al., (2010) the NDF digestibility would be determined by lignification.

\section{Conclusion}

- Forage production of L. leucocephala in the Amarasi plantation is higher than Selobua and Mamar Kering plantation. However, the L. leucocephala production in three planting systems did not affect by different seasons.

- The overall nutritional content and in vitro digestibility of L. leucocephala was better during rainy season, and the highest was found in Selobua plantation.

\section{References}

AOAC. (1980), "Official Methods of Analysis of the Association of Official Analytical Chemists 13 ${ }^{\text {th }}$ Ed.", Benyamin Franklin Station, Washington DC. 
Aregheore, E. M. (2002), "Voluntary Intake and Digestibility of Fresh, Wilted and Dry Leucaena (Leucaena leucocephala) at Four Levels to a Basal Diet of Guinea Grass (Panicum maximum)", Asian-Aust J Anim Sci 15(8) 1139-1146.

Askar, S. (1997), "Nilai Gizi Daun Lamtoro dan Pemanfatannya Sebagai Pakan Ternak Ruminansia", Lokakarya Fungsional Non Peneliti 110-115.

Chairudin, Efendi \& Sabaruddin. (2015), "Dampak naungan terhadap perubahan karakter agronomi dan morfofisiologi daun pada tanaman kedelai (Glycine max (L.) Merril)", J Floratek 10 26-35.

Crowder, L. V. \& Chheda, H. B. (1982), “Tropical Grassland Husbandry $1^{\text {st }}$ Ed.”, Longman Inc., New York.

Delsalle, L., Perez, R., Dedieu, B., Girard, N., Hang, G., Larrañaga, G. \& Magda, D. (2012), "Adaptive Strategies of Cattle Livestock Farmers Facing Multiple Uncertainties in a District of the Argentinean Pampa", Proceedings of the $10^{\text {th }}$ Europe IFSA Symposium, unpaginated.

Edward, A., Mlambo, V., Lallo, C. H. O. \& Garcia, G. W. (2012), "Yield, Chemical Composition and In Vitro Ruminal Fermentation of the Leaves of Leucaena leucocephala, Gliricidia sepium and Trichanthera gigantea as Influenced by Harvesting Frequency", Journal of Animal Science Advances 2, 321-331.

Egan, A. R., Wanapat, M., Doyle, P. T., Dixon, R. M. \& Pearce, G. R. (1985), "Production Limitations of Intake, Digestibility and Rate of Passage", Forage in South East Asian and South Pacific Agriculture ACIAR Proceeding, 104-110

Elfeed, A. A. \& Elmagboul, A. H. (2016), "Effect of Planting Density on Leucaena leucocephala Forage and Woody Stems Production Under Arid Dry Climate", International Journal of Environmental and Agriculture Research 2(3), 7-11.

Goering, H. K. \& Van-Soest, P. J. (1970), "Forage fiber analysis", USDA, Washington DC.

Handriawan, A., Respatie, D. W. \& Tohari. (2016), "Pengaruh Intensitas Naungan Terhadap Pertumbuhan dan Hasil Tiga Kultivar Kedelai (Glycine $\max ($ L.) Merril) di Lahan Pasir Pantai Bugil, Kulon Progo", Vegetalika 5(3), 1-14.

Kapa, M. M. J. (2007), "Produktivitas Usaha Tani dalam Sistem Pertanian Terpadu: Studi Kasus di Kecamatan Amarasi, Kabupaten Kupang, Nusa Tenggara Timur", Proceedings of a Workshop to Identify Sustainable Rural Livelihood, 126.

Keraf, F. K., Nulik, Y. \& Mullik, M. L. (2015), "Pengaruh Pemupukan Nitrogen dan Umur Tanaman terhadap Produksi dan Kualitas Rumput Kume (Sorghum plumosum var. timorense)", Indonesian Journal of Animal Science 17(2), 123-130.

Kim, D. J. \& Jang, S. H. (1988), "Study of the Fiber Characteristics, Cell Wall-Nitogen and Dry Matter Digestibility in Wild Legume Shrubs", Korean Journal of Animal Sciences 29(9), 399-407.

Koten, B. B., Soetrisno, R. D., Ngadiyono, N. \& Suwignyo, B. (2012), "Produksi Tanaman Sorgum (Sorghum bicolor (L.) Moench) Varietas Lokal Rote sebagai Hijauan Pakan Ruminansia pada Umur Panen dan Dosis Pupuk Urea yang Berbeda”, Buletin Peternakan 36(3), 150-155.

Makkar, H. P. S. (2002), "Project Summary: Development and Field Evaluation of Animal Feed Suplementation Packages (AFRA Project II-17 - RAF/5/041)", Proceedings of the Final Review Meeting of an IAEA Technical Cooperation Regional AFRA Project.

Mannetje, L. T. \& Jones, R. M. (2000), "Sumberdaya Nabati Asia Tenggara”, Balai Pustaka, Indonesia.

McDonald, P., Edward, R. A., Greenhalgh, J. F. D., Morgan, C. A., Sinclair, L. A. \& Wilkinson, R. G. (2010), "Animal Nutrition $7^{\text {th }}$ Ed.", Prentice Hall, New York.

Njurumana, G. N. D. (2008), "Rehabilitasi Lahan Kritis Berbasis Agrosylvopastur di Timor dan Sumba, Nusa Tenggara Timur", Info Hutan 5(2), 99-112.

Nulik, J., Hau, D. K. \& Asnah. (2000), "The Amarasi Farming System, Its Economic Aspects and the Adoption on Improved Cattle Feeding and Group Pen Systems", Proceedings of an International Workshop, 95.

Rimbawanto, E. A., Yusiati, L. M., Baliarti, E. \& Utomo, R. (2015), "Effect of Condensed Tannin of Leucaena and Calliandra Leaves in Protein Trash Fish Silage on In Vitro Ruminal Fermentation, Microbial Protein Synthesis and Digestibility", Animal Production 17(2), 83-91.

Roshetko, J. M. \& Mulawarman. (2002), "Wanatani di Nusa Tenggara: Ringkasan Hasil Lokakarya”, Prosiding Lokakarya Wanatani Se-Nusa Tenggara. ICRAF dan Winrock International.

Simbaya, J. (2002), "Potential of Fodder Tree/Shrub Legumes as a Feed Resource for Dry Season Supplementation of Smallholder Ruminant Animals", Proceedings of the Final Review Meeting of an IAEA Technical Cooperation Regional AFRA Project.

Smith, T. (2002), "Some Tools to Combat Dry Season Nutritional Stress in Ruminants under African conditions", Proceedings of the Final Review Meeting of an IAEA Technical Cooperation Regional AFRA Project.

Soltan, Y. A., Morsy, A. S., Sallam, S. M. A., Louvandini, H. \& Abdalla, A. L. (2012), "Comparative In Vitro Evaluation of Forage Legumes (Prosopis, Acacia, Atriplex, and Leucaena) on Ruminal Fermentation and Methanogenesis", Journal of Animal and Feed Sciences 21(4), 759-772.

Sulistijo, E. D. (1994), "Pengaruh Cara dan Interval Pemangkasan terhadap Produktifitas Hijauan Tanaman 
Gamal (Gliricidia sepium Jacq) di Daerah Kapur Malang Selatan”, Master Thesis, University of Brawijaya. Sulistijo, E. D. \& Rosnah, U. S. (2013), "Penyediaan Pakan Sapi Bali Berbasis Kearifan Lokal Di Kabupaten Kupang Propinsi Nusa Tenggara Timur”, Faculty of Animal Husbandry, Universitas Cendana, Indonesia.

Tilley, J. M. A. and Terry, R. A. (1963), "A two-stage technique for the digestion of forage crops", Grass and Forage Science 18(2), 104-111. 